\title{
ANALISIS KESALAHAN BERBAHASA PADA TEKS BIOGRAFI BUATAN SISWA KELAS X SMK NEGERI 6 KOTA BENGKULU
}

\author{
'Oktariyarti Hendri; ${ }^{2}$ Agus Joko Purwadi; ${ }^{3}$ Padi Utomo \\ 1,2,3 Program Studi Pendidikan Bahasa Indonesia Fakultas Keguruan dan Ilmu \\ Pendidikan Universitas Bengkulu
}

Abstrak

\section{Korespondensi: Oktariyartihendri15@gmail.com}

Tujuan penelitian ini untuk mengetahui dan mendeskripsikan bentuk kesalahan berbahasa yang terdapat dalam teks biografi buatan siswa kelas X SMK Negeri 6 Kota Bengkulu. Kesalahan tersebut dianalisis dengan menggunakan metode Tarigan (1988). Penelitian ini menggunakan metode deskriptif dengan pendekatan kualitatif. Data dari penelitian ini adalah seluruh tulisan yang berupa huruf, kata dan kalimat dalam teks biografi karya siswa yang mengandung kesalahan. Sedangkan sumber data dalam penelitian ini berupa dokumen, yaitu teks biografi karya siswa kelas $\mathrm{X}$ APHP sebanyak 18 teks. Teknik pengumpulan data menggunakan teknik dokumentasi, yaitu peneliti mengumpulkan tulisan siswa yang berisi teks biografi atau hal yang dianggap berhubungan dengan penelitian yang sedang dilakukan. Hasil penelitian ini adalah ditemukannya beberapa kesalahan pada teks biografi buatan siswa dengan total 164 kesalahan. 1. Kesalahan pada tataran fonologi sebanyak 41 kesalahan dengan persentase $25 \%$., 2. Kesalahan pada tataran morfologi sebanyak 13 kesalahan dengan persentase $8 \%$., 3. Kesalahan pada tataran sintaksis sebanyak 36 kesalahan dengan persentase $22 \%$., 4. Kesalahan tataran wacana sebanyak 4 kesalahan dengan persentase 2,5\%., 5. Kesalahan tataran ejaan sebanyak 70 kesalahan dengan persentase $52 \%$. Dari delapan belas teks biografi yang dianalisis dapat disimpulkan bahwa masih banyak kesalahan yang ditemukan dari tulisan siswa, terutama pada tataran ejaan paling banyak ditemukan kesalahan baik dalam penggunaan huruf kapital dan penggunaan tanda baca. Setelah dianalisis setiap kesalahan tersebut diberikan perbaikan tulisan.

Kata Kunci: Analisis kesalahan berbahasa, teks biografi

\section{Abstract}

The purpose of this study was to determine and describe the forms of language errors contained in biographical texts made by class X students of SMK Negeri 6 Kota Bengkulu. These errors were analyzed using the Tarigan (1988) method. This study uses a descriptive method with a qualitative approach. The data from this study were all writings in the form of letters, words and sentences in the biographical texts of the students' work that contained errors. While the source of data in this study was a document, namely 18 texts of biographical texts written by class $\mathrm{X}$ APHP students. The data collection technique uses documentation techniques, namely researchers collect student writings containing biographical texts or things that are considered related to the research being carried. The results of this study were the finding of several errors in the biographical text made by students with a total of 164 errors. 1. Errors at the phonological level were 41 errors with a 


\section{Oktariyarti Hendri; Agus Joko Purwadi; Padi Utomo}

percentage of $25 \%$, 2. Errors at the morphological level were 13 errors with a percentage of $8 \%$., 3. Errors at the syntactic level were 36 errors with a percentage of $22 \%$., 4. Errors at the level of discourse as many as 4 errors with a percentage of $2.5 \%$., 5. Error level spelling as many as 70 errors with a percentage of $52 \%$. From the eighteen biographical texts analyzed, it can be concluded that there are still many errors found in students' writing, especially at the spelling level, the most errors were found in both the use of capital letters and the use of punctuation marks. After analyzing each error, the writing was corrected.

Keywords: language error analysis, biographical text

\section{PENDAHULUAN}

Bahasa merupakan alat komunikasi dan kerja sama yang sangat efektif. Maka dapat dikatakan bahasa memiliki peranan yang penting bagi kehidupan sehari-hari dan tak akan terlepas dari kehidupan manusia. Bahasa memiliki fungsi-fungsi tertentu yang digunakan berdasarkan kebutuhan seseorang, yakni sebagai alat mengekspresikan diri, sebagai alat berkomunikasi, sebagai alat untuk mengadakan integrasi dan beradaptasi sosial dalam lingkungan atau situasi tertentu, dan sebagai alat untuk melakukan kontrol sosial (Keraf, 1997:1). Pada proses pembelajaran, bahasa memegang peranan yang penting untuk menyampaikan ilmu dan pengetahuan, guru dan peserta didik dapat melakukan interaksi menggunakan bahasa. Berarti guru menyampaikan materi pembelajaran dan peserta didik mencerna dan merespons apa yang telah disampaikan oleh para guru.

Pembelajaran bahasa diharapkan dapat membantu peserta didik menemukan gagasan serta meningkatkan partisipasi peserta didik didalam masyarakat. Pada pembelajaran bahasa Indonesia diarahkan dapat meningkatkan keterampilan berbahasa peserta didik. Terdapat empat komponen dalam keterampilan bahasa, dan salah satunya ialah keterampilan menulis. Menulis ialah suatu kegiatan kreatif dalam menggunakan bahasa lisan yang diungkapkan ke dalam bentuk bahasa tulis. Keterampilan dalam menuliskan sesuatu tentunya tidak datang begitu saja, melainkan membutuhkan banyak latihan untuk menghasilkan tulisan yang baik. Untuk itu menulis memiliki peranan penting dalam melihat dan menilai kemampuan menalar peserta didik dalam menyampaikan isi pikirannya. Sekolah sebagai tempat formal berlangsungnya proses belajar mengajar harus menjadikan peserta didik mampu menulis dengan baik dan benar, untuk itu selama proses pembelajaran, peserta didik dituntut agar mampu menuliskan teks sesuai dengan aturan penulisan. Kemampuan menulis yang harus dikuasai peserta didik tingkat SMK kelas $\mathrm{X}$ salah satunya ialah menulis teks biografi yang tertera di dalam pembelajaran Kurikulum 2013.

Kemampuan menulis teks biografi adalah kegiatan penuangan berupa tulisan yang berisi kisah tokoh atau pelaku, peristiwa, dan masalah yang dihadapinya (Kemendikbud, 2014:37). Menulis teks biografi atau menceritakan kembali teks biografi dalam bentuk lisan maupun tulisan terdapat dalam pembelajaran bahasa Indonesia kurikulum 2013 kelas X, pembelajaran ini terdapat dalam KD 3.15 dan 4.15. Dalam melakukan kegiatan keterampilan menulis tentu saja harus memerhatikan aturan-aturan dalam penulisan. Untuk hal menulis, peserta didik sering kali melakukan kesalahan berbahasa dalam penulisan, hal tersebut terjadi karena kebanyakan dari peserta didik belum memahami benar bagaimana aturan-aturan dalam penulisan, dan bagaimana tulisan yang sesuai dengan kaidah penulisan yang seharusnya, peserta didik masih banyak 
yang belum mengetahui aturan penulisan yang sesuai dengan penggunaan bahasa ya ng baik dan benar, sehingga muncul kesalahan berbahasa dengan berbagai jenis tataran. Kesalahan berbahasa adalah penggunaan bahasa yang menyimpang atau salah dari kaidah bahasa yang berlaku. Banyak kesalahan yang terdapat dalam karya yang para siswa buat, untuk itu perlu dilakukannya analisis terhadap penulisan teks yang telah dibuat oleh peserta didik. Agar nantinya kesalahan tersebut dapat diminimalisir dan akhirnya tidak ada lagi kesalahan pada teks yang mereka tulis.

Analisis kesalahan bahasa adalah suatu prosedur kerja yang biasa dilakukan oleh peneliti ataupun guru bahasa di sekolah, yang dalam hal ini meliputi kegiatan mengumpulkan data, mengumpulkan sampel kesalahan, mengidentifikasi kesalahan yang terdapat dalam sampel, menjelaskan kesalahan tersebut, mengklasifikasi kesalahan, dan mengevaluasi taraf keseriusan kesalahan (Setyawati, 2010:18) sedangkan menurut Tarigan (Bambang Yulianto, 2010:25) mendefinisikan bahwa analisis kesalahan berbahasa merupakan kajian terhadap segala aspek kesalahan dalam pembelajaran bahasa. Peneliti melakukan analisis mengenai kesalahan berbahasa yang terdapat dalam tulisan teks biografi karya peserta didik, agar mengetahui di bagian mana sajakah peserta didik cenderung banyak melakukan kesalahan dan pada akhirnya dapat memberikan pembetulan pada bagian yang salah tersebut. Serta memberikan gambaran mengenai aturan penulisan yang sesuai dengan aturan dan kaidah penulisan.

Penelitian ini mencakup analisis mengenai kesalahan berbahasa lingkup linguistik yang terbagi lagi menjadi beberapa tataran, yaitu fonologi, morfologi, semantik, sintaksis, wacana dan ejaan (Setyawati, 2010:48). Pada penelitian ini teori yang digunakan dalam melakukan analisis kesalahan berbahasa ialah teori dari Tarigan (1988), yaitu 1. Pengumpulan data, 2. Identifikasi kesalahan data, 3. Penjelasan kesalahan data, 4. Klasifikasi kesalahan dan penyebab terjadinya suatu kesalahan, 5. Evaluasi taraf keseriusan kesalahan itu. Analisis ini sangat berguna untuk membantu berlangsungnya kelancaran program pembelajaran, agar dalam hal ini guru dapat mengatasi kesulitan yang dihadapi para siswa.

Penelitian analisis kesalahan berbahasa juga sudah diteliti oleh Ira Wibowo dengan judul Analisis kesalahan berbahasa dalam teks cerita pendek karya siswa kelas IX SMP KAnisius Sleman tabun 2015/2016. Penelitian yang dilakukan pada tahun 2016 itu berfokus pada kesalahan ejaan dan kalimat dengan teks cerita pendek. Penelitian itu bertujuan untuk (1) mendeskripsikan kesalahan ejaan, dari huruf kapital, unsur serapan dan tanda baca. (2) mendeskripsikan kesalahan kalimat, kalimat kekurangan unsur dan kalimat ambigu. Subjek pada penelitian tersebut adalah siswa kelas IX SMP KANISIUS SLEMAN. Kesalahan paling banyak yang ditemukan dalam penelitian tersebut yaitu pada penggunaan tanda baca, dibuktikan dengan ditemukannya 235 kesalahan. Penelitian selanjutnya dilakukani oleh Netty Fitria Dinanti dengan judul Analisis kesalahan penggunaan bahasa Indonesia pada jurnal ilmiah MIP A FKIP Universitas Bengkulu. Penelitian ini berfokus pada kesalahan penggunaan bahasa pada jurnal ilmiah MIPA edisi terbit tahun 2018 yang ditinjau dari bidang ejaan, diksi, kalimat dan paragraf. Kesalahan yang paling banyak ditemukan dalam penelitian ini ialah pada tataran ejaan.

Tujuan dari artikel ini untuk mengetahui dan mendeskripsikan bentuk kesalahan berbahasa pada teks biografi buatan siswa kelas X SMK Negeri 6 Kota Bengkulu. Permasalahan dalam penelitian ini yaitu bagaimana bentuk kesalahan pada teks biografi 
buatan siswa kelas X SMK Negeri 6 Kota Bengkulu. Penelitian ini juga memiliki manfaat, yaitu manfaat secara teoretis dan manfaat secara praktis.

\section{METODE}

Metode yang digunakan dalam penelitian ini adalah metode deskriptif dengan pendekatan kualitatif. (Arikunto, 2013:3) menyatakan bahwa penelitian deskriptif adalah penelitian yang dimaksudkan untuk menyelidiki keadaan, kondisi, wilayah, atau hal-hal lain tanpa mengubah, menambah atau mengadakan manipulasi, kemudian memaparkan apa yang terjadi dalam bentuk laporan penelitian serta apa adanya. Penelitian deskriptif dilakukan untuk memberikan gambaran yang lebih detail mengenai suatu gejala atau fenomena. Hasil akhir dari penelitian ini biasanya berupa tipologi atau pola-pola mengenai fenomena yang sedang dibahas (Prasetyo dan Jannah, 2014:42). Penelitian ini dilakukan di SMK Negeri 6 Kota Bengkulu yang terletak di Kampung Bahari No. 100, Kecamatan Kampung Melayu Kota Bengkulu. Penelitian dilakukan pada bulan September 2020.

Adapun teknik pengambilan data pada penelitian ini menggunakan teknik dokumentasi. Dokumentasi dalam penelitian ini meliputi absensi siswa dan data tulisan siswa berupa teks biografi sebanyak 18 teks. Teknik analisis data dalam penelitian ini, yaitu 1. Mengidentifikasi, 2. Mengklasifikasikan kesalahan, 3. Menguraikan kesalahan, 4. memperbaiki kesalahan..

\section{HASIL DAN PEMBAHASAN}

Hasil penelitian analisis kesalahan berbahasa pada teks biografi buatan siswa kelas X SMK Negeri 6 Kota Bengkulu, ditemukan 5 kesalahan dari 18 teks biografi karya siswa tersebut yaitu, kesalahan bahasa tataran fonologi, morfologi, sintaksis, wacana dan ejaan.

1. Kesalahan tataran fonologi

Kesalahan berbahasa pada tataran fonologi ini dapat terjadi baik lisan maupun bentuk tulisan. Kesalahan fonologi ini kerapkali terjadi karena ketidaktahuan atau bahkan ketidaksengajaan karena kurang fokusnya para siswa.

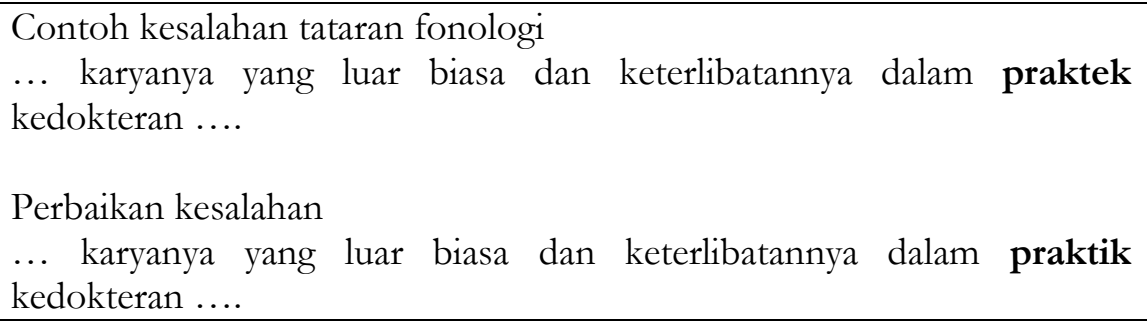

Pada kata praktek yang seharusnya dituliskan secara benar menjadi praktik. Adanya perubahan fonem i menjadi fonem e. kesalahan tersebut seringkali ditemukan dalam tulisan para siswa, banyak hal yang mendasari hal tersebut dapat terjadi. Salah satunya ialah karena terpengaruh terhadap bahasa yang kerap ia dengar dan ia ucapkan, hingga terpengaruh dalam penulisan.

2. Kesalahan tataran morfologi

Selanjutnya pada bagian ini peneliti akan membahas mengenai kesalahan pada tataran morfologi. Morfologi adalah ilmu yang mempelajari seluk-beluk bentuk kata serta pengaruh perubahan-perubahan bentuk kata tersebut. Dalam hal ini baik ragam 
tulis maupun ragam lisan dapat terjadi kesalahan berbahasa dalam pembentukan kata atau tataran morfologi.

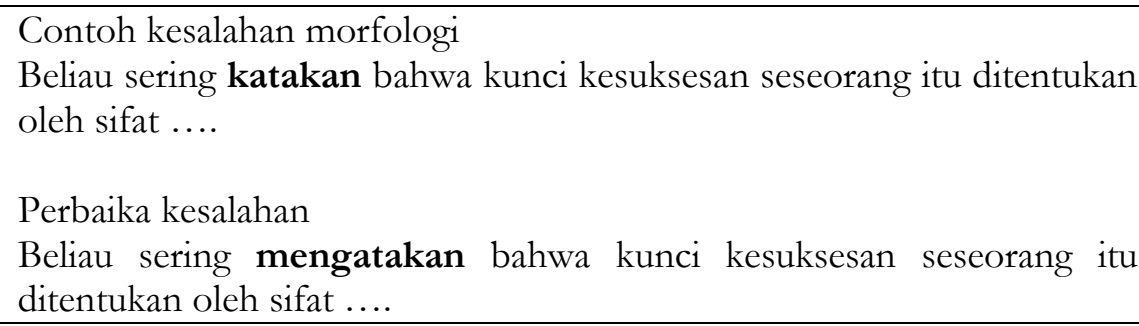

Seharusnya pada kalimat di atas ditambahkan dengan imbuhan meng-, sehingga dituliskan secara benar menjadi mengatakan. Ada istilah ekonomi bahasa, artinya sebagai pengguna bahasa dapat menggunakan kata sehemat mungkin, namun penghematan ini jangan sampai merusak kaidah bahasa baik secara penulisan ataupun pelafalan. Ada waktunya kita dapat menerapkan ekonomi bahasa sesuai dengan konteksnya.

3. Kesalahan tataran sintaksis

Sintaksis adalah cabang ilmu linguistic tentang susunan kalimat dan bagianbagiannya. Kesalahan dalam tataran sintaksis berhubungan erat dengan kesalahan morfologi, karena kalimat adalah susunan kata-kata yang disatukan hingga dapat membentuk makna.

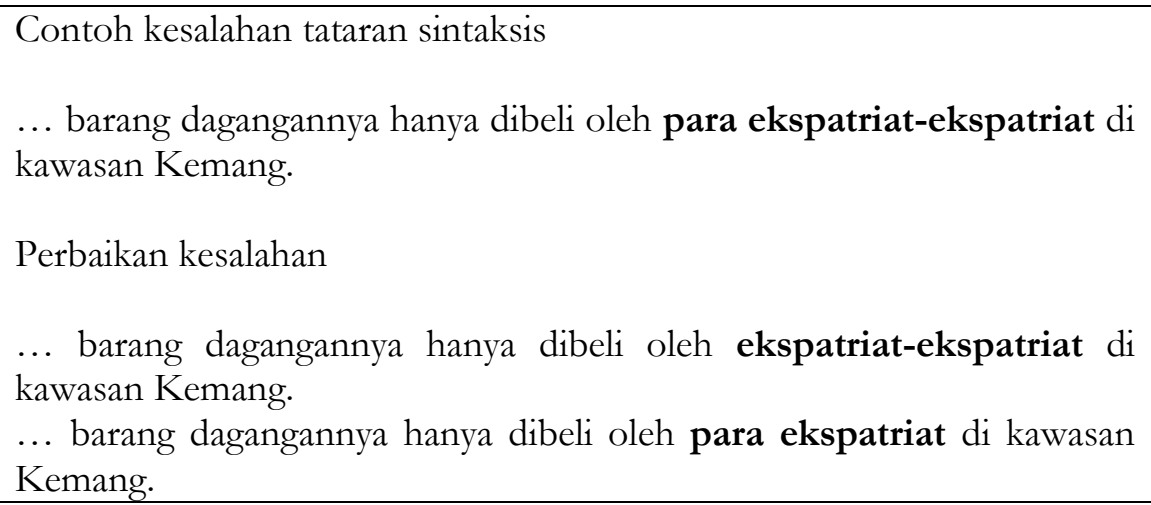

Dalam penggunaan bahasa terkadang siswa masih salah menggunakan bentuk jamak dalam bahasa Indonesia, sehingga terjadi bentuk yang rancu atau kacau karena adanya penjamakan yang ganda. Dalam kalimat untuk penanda jamak sebuah kata cukup menggunakan satu penanda saja, jika sudah terdapat penanda jamak tidak perlu kata tersebut diulang atau sebaliknya, jika kata tersebut sudah diulang tidak perlu menggunakan tanda jamak. Pada contoh data kesalahan di atas terdapat kata jamak para dan kata ekspatriat yang di ulang. Seharusnya siswa menggunakan salah satu di antara dua kata yang ditebalkan.

4. Kesalahan tataran wacana

Wacana merupakan satuan bahasa terlengkap dan tertinggi di atas kalimat atau klausa dengan koherensi dan kohesi tinggi yang berkesinambungan secara lisan atau tertulis 
Contoh kesalahan tataran wacana

Raden Achmad Soebardjo adalah menteri luar negeri pertama Indonesia, Raden Achmad Soebardjo mempunyai gelar meester in de rechten yang diperoleh dari universitas di Belanda.

Perbaikan kesalahan

Raden Achamd Soebardjo adalah menteri luar negeri pertama Indonesia, ia mempunyai gelar meester in de rechten yang diperoleh dari universitas di Belanda.

Kata-kata yang ditebalkan dalam data di atas merupakan penggunaan yang kurang efektif. Agar suatu kalimat menjadi efektif, ekonomis. Maka sebaiknya yang ditebalkan itu mengalami pelesapan, yaitu penghilangan nama tokoh yang dituliskan secara berulang.

5. Kesalahan tataran ejaan

Dalam melakukan analisis mengenai penggunaan ejaan, peneliti menggunakan Pedoman Umum Ejaan Bahasa Indonesia sebagai acuan. Pedoman ini mencakup semua ketentuan ejaan yang benar sesuai dengan kaidah ejaan dalam bahasa Indonesia.

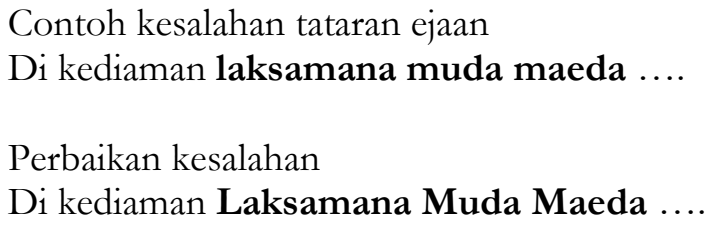

Contoh kesalahan tataran ejaan

Di kediaman laksamana muda maeda ....

Perbaikan kesalahan

Di kediaman Laksamana Muda Maeda ....

Pada contoh data kesalahan di atas terdapat kesalahan penulisan huruf kapital, yaitu nama tokoh yang tidak ditulis dengan huruf kapital secara sempurna. Sesuai kaidah penulisan huruf dalam PUEBI bahwa dalam menulis nama orang atau julukan harus menggunakan huruf kapital.

\section{Tabel 1 jumlah kesalahan berbahasa pada teks biografi}

\begin{tabular}{cccccc}
\hline $\begin{array}{c}\text { Kode } \\
\text { teks }\end{array}$ & $\begin{array}{c}\text { Tataran } \\
\text { fonologi }\end{array}$ & $\begin{array}{c}\text { Tataran } \\
\text { morfologi }\end{array}$ & $\begin{array}{c}\text { Tataran } \\
\text { sintaksis }\end{array}$ & $\begin{array}{c}\text { Tatarn } \\
\text { wacana }\end{array}$ & $\begin{array}{c}\text { Tataran } \\
\text { ejaan }\end{array}$ \\
\hline TB1 & 7 & 5 & 5 & - & 4 \\
TB2 & 7 & 1 & 4 & - & 5 \\
TB3 & 4 & - & 3 & 1 & 5 \\
TB4 & - & 1 & 5 & - & 7 \\
TB5 & 6 & - & 6 & - & 3 \\
TB6 & - & - & - & 1 & 5 \\
TB7 & - & - & 4 & 2 & 3 \\
TB8 & 4 & - & - & - & 2 \\
TB9 & 2 & 2 & 4 & - & 4 \\
TB10 & 1 & 1 & 2 & - & 3 \\
TB11 & 6 & - & - & - & 4 \\
TB12 & 1 & - & 3 & - & 2 \\
TB13 & - & - & 4 & - & 2 \\
TB14 & - & - & - & - & 2
\end{tabular}




\begin{tabular}{cccccc} 
TB15 & 1 & - & - & - & 3 \\
B16 & 1 & - & - & - & 1 \\
B17 & - & 2 & - & - & 5 \\
B18 & 1 & - & - & - & 4 \\
Jumlah & 41 & 13 & 36 & 4 & 70 \\
\hline
\end{tabular}

Tabel di atas adalah jumlah keseluruhan kesalahan yang ditemukan dari tiap jenis tataran kesalahan, dengan jumlah secara garis besar yaitu 164 kesalahan dengan masing-masing persentase kesalahan. Pada tataran fonologi sebanyak 41 kesalahan dengan persentase kesalahan 25\%, tataran morfologi sebanyak 13 kesalahan dengan persentase $8 \%$, tataran sintaksis sebanyak 36 kesalahan dengan persentase $22 \%$, tataran wacana sebanyak 4 kesalahan dengan persentase $2,5 \%$, tataran ejaan sebanyak 70 kesalahan dengan persentase $52 \%$.

Dari seluruh kesalahan yang ditemukan dalam teks biografi buatan siswa, paling dominan terdapat kesalahan pada tataran ejaan. Khususnya pada penggunaan huruf kapital di dalam penulisan para siswa. Pemaparan di atas menunjukkan bahwa pemahaman siswa kelas X SMK Negeri 6 Kota Bengkulu jurusan APHP terhadap ejaan masih kurang dan harus lebih ditingkatkan. Untuk kesalahan yang lain pun juga harus diperhatikan dan diberikan pemahaman, hal itu bertujuan untuk menghindari kesalahan yang sama di kemudian hari.

Banyak hal yang melatarbelakangi terjadinya kesalahan pada tulisan siswa tersebut, yaitu :

a. Terpengaruh terhadap bahasa yang lebih dulu dikuasainya. Ini dapat berarti bahwa kesalahan berbahasa disebabkan interferensi bahasa ibu atau bahasa pertama (B1) terhadap bahasa kedua (B2) yang sedang dipelajari siswa.

b. Kurangnya kesadaran siswa dalam mencari informasi mengenai penulisan yang sesuai dengan kaidah penulisan bahasa Indonesia. siswa hanya menerima apa yang disampaikan oleh guru pada saat jam pelajaran. Jadi pengetahuan siswa terhadap kaidah penulisan yang baik dan benar sedikit kurang.

c. Kurang telitinya siswa saat menulis, mereka harusnya lebih konsentrasi lagi dan membuang fikiran yang penting selesai. Karena anggapan tersebut sudah pasti salah. Hal tersebut agar kesalahan-kesalahan tersebut tidak terjadi lagi.

d. Kurang pahamnya siswa terhadap kaidah bahasa yang seharusnya. Ini bisa menjadi faktor dari kesalahan yang dilakukan oleh siswa, karena ketidaktahuan mereka dengan aturan penulisan atau kaidah yang baik dan benar dalam bahasa Indonesia. entah itu salah ataupun keliru dalam pemahaman mengenai kaidah penulisan yang menyebabkan kesalahan dalam penulisan.

e. Pengajaran bahasa yang kurang tepat atau kurang sempurna. Hal ini berkaitan dengan bahan yang diajarkan atau yang dilatihkan dan cara pelaksanaan pengajaran. Bahan pengajaran menyangkut masalah sumber, pemilihan, penyusunan, pengurutan. Cara pengajaran menyangkut pada masalah teknik penyajian, langkah-langkah urutan penyajian, kesinambungan pengajaran, dan alat-alat bantu dalam pengajaran. 


\section{PENUTUP}

\section{Simpulan}

Berdasarkan hasil penelitian dan pembahasan terhadap adanya kesalahan berbahasa dalam teks biografi buatan siswa kelas X SMK Negeri 6 Kota Bengkulu seperti yang dijelaskan dan dijabarkan oleh peneliti, maka dapat ditarik simpulan sebagai berikut. Ditemukan 5 jenis kesalahan berbahasa dengan total 164 kesalahan, yang terdiri dari kesalahan fonologi sebanyak 41 kesalahan dengan persentase $25 \%$, kesalahan morfologi sebanyak 13 kesalahan dengan persentase 8\%, kesalahan sintaksis sebanyak 36 kesalahan dengan persentase $22 \%$, kesalahan wacana sebanyak 4 kesalahan dengan persentase $2,5 \%$, kesalahan ejaan sebanyak 70 kesalahan dengan persentase $52 \%$.

Kesalahan terbanyak terdapat pada tataran ejaan dengan jumlah sebanyak 70 kesalahan dengan berbagai macam kesalahan.Dari keseluruhan jumlah yang didapat dari setiap kesalahan, dapat dikatakan bahwa para siswa masih sangat memerlukan pengajaran, pembelajaran, latihan dan konsentrasi lebih serta pengetahuan mengenai aturan dalam penulisan, agar diharapkan dapat meminimalkan kesalahan bahkan pada akhirnya menghilangkan kesalahan tersebut.

\section{Saran}

Berdasarkan dari hasil pengkajian hasil penelitian, maka peneliti bermaksud memberikan saran yang mudah-mudahan dapat bermanfaat bagi lembaga maupun peneliti yang selanjutnya.

Guru hendaknya memberikan pengetahuan tentang kebahasaan kepada para siswa di setiap proses pembelajaran yang dilakukan agar siswa dapat mengetahui kaidah kebahasaan Indonesia dan siswa diharapkan dapat mencari referensi dan informasi lainnya di luar dari jam pelajaran sekolah untuk menambah pengetahuan tentang kebahasaan serta siswa agar lebih teliti dan fokus dalam mengerjakan teks yang ditugaskan oleh guru. Kemudian untuk peneliti selanjutnya diharapkan dapat mengkaji sumber ataupun referensi yang dapat mendukung lebih banyak lagi terkait dengan penelitian yang serupa ini dan diharapkan mempersiapkan diri dalam proses pengambilan dan pengumpulan data, sehingga penelitian ini akan lebih baik lagi.

\section{DAFTAR RUJUKAN}

Arifin Zaenal dan Farid Hadi. 2009. 1001 Kesalahan Berbahasa. Jakarta: CV Akademika Pressindo.

Dinanti, Netty Fitria. 2019. Analisis Kesalaban Penggunaan Bahasa Indonesia Pada Jurnal Ilmiah MIPA FKIP Universias Bengkulu. E-journal Unib, Volume 3, Nomor 2, Agustus 2019

Harimansyah, Ganjar dkk. 2016. Pedoman Umum Ejaan Bahasa Indonesia. Jakarta : Badan Pengembangan Dan Pembinaan Bahasa.

Kosasih, E. 2013. Cerdas Berbahasa Indonesia untuk SMA/MA Kelas X. Jakarta : Erlangga.

Pateda, Mansoer. 1987. Analisis Kesalahan. Gorontalo: Nusa Indah.

Semiawan Conny dan JR.Raco. 2017. Metode Penelitian Kualitatif. Jakarta : PT

Gramedia Widiasarana Indonesia Kompas Gramedia Building. 
Analisis Kesalahan Berbahasa Pada Teks Biografi Buatan Siswa Kelas X SMK...

Setyawati, Nanik. 2010. Analisis Kesalahan Berbahasa Indonesia Teori dan Praktik. Surakarta: Yuma Pustaka.

Tarigan, Henry Guntur dan Djago Tarigan. 1988. Pengajaran Analisis Kesalahan. Bandung:Angkasa. 